Special Issue of the 6th International Congress \& Exhibition (APMAS2016), Maslak, Istanbul, Turkey, June 1-3, 2016

\title{
Investigation of the Effect of Different Heat Treatments on Wear Behavior of AA7075 Alloy
}

\author{
A. KALYON* AND D. ÖZYÜREK \\ Karabuk University, Technology Faculty, Manufacturing Eng., 78100 Karabuk-Turkey
}

\begin{abstract}
In this study, wear behavior of AA7075 alloy applied different ageing heat treatments is examined. During each ageing heat treatment, the relevant samples are processed with solid solution at $485{ }^{\circ} \mathrm{C}$ for $2 \mathrm{~h}$. After the quenching process, ageing processes were performed. The T6 heat treatment is applied at $120^{\circ} \mathrm{C}$ for $24 \mathrm{~h}$. Along the re-ageing heat treatment process, samples undergone the T6 process is taken into the solid solution at $120^{\circ} \mathrm{C}$ once more and aged at the given temperature for $24 \mathrm{~h}$. In the high temperature heat treatment process, the samples are pre-precipitated at $445^{\circ} \mathrm{C}$ for $30 \mathrm{~min}$ and then taken to ageing process at $120^{\circ} \mathrm{C}$ for $24 \mathrm{~h}$. Wear tests are carried out at $1 \mathrm{~m} / \mathrm{s}$ constant sliding speed and under $20 \mathrm{~N}$ load along four different sliding distances $(300-1200 \mathrm{~m})$. The amount of precipitation observed from the structure exhibits difference at the second phase with respect to applied ageing heat treatment. Finest precipitation particle is observed with T6 heat treatment and the coarse precipitation is with the high temperature heat treatment. Furthermore, a relationship is determined between dimension of the second phase precipitation and hardness values.
\end{abstract}

DOI: 10.12693/APhysPolA.131.150

PACS/topics: $81.40 . P q$

\section{Introduction}

Durable residual-strengthened AA7075 alloys are widely used in aviation industry due to their highresistance, ductility, toughness, and tensile strengths. The most prominent functions expected from these alloys used in the aerospace industry are good fatigue resistance and wear resistance [1-3]. The most common method to increase strength in AA7075 aluminum alloys is ageing process. Resistance of these alloys could be developed significantly through different ageing processes. Artificial ageing (T6), re-ageing (RRA) and creating pre-precipitation at high temperature (HTPP) are considered among these ageing heat treatment processes [4-6]. The resistance of alloy is improved through ageing heat treatment, following solid solution and quenching processes, due to second phase precipitation formed in the structure by ageing. In the $7 \mathrm{xxx}$ - series aluminum alloys, $\mathrm{T} 6$ heat treatment ensures superior hardness and resistance. T6 heat treatment is applied for the 7075 aluminum alloy at $120^{\circ} \mathrm{C}$ for $24 \mathrm{~h}$ ageing process [7]. At the end of the process, since corrosion sensitivity of the alloy increases, T73 heat treatment is developed to increase corrosion resistances of these types of alloys. By means of this heat treatment process the corrosion resistance of alloys exhibits significant increase but strength of the alloy decreases by $10-15 \%[8,9]$. In order to ensure resistance and improve the corrosion characteristics of aluminum alloys to optimum levels, retrogression, RRA and forming preliminary-precipitation at HTPP heat treatments are applied. The RRA heat treatment is considered as an important process since aluminum alloys are

*corresponding author; e-mail: alikalyon@karabuk.edu.tr used to construct the main body for $65 \%$ of commercial airplanes. Especially 7150 and 7075-type aluminum alloys are developed for the RRA process [10].

In this study, effects of various heat treatment processes on wear behaviors of AA7075 aluminum alloys are investigated experimentally. Wear test results are evaluated based on the micro-structure characterization, X-ray diffraction (XRD) and scanning electron microscopy (SEM) studies.

\section{Materials and method}

Table I gives the chemical composition of the AA7075 aluminum alloy used in the experimental studies. Wear performance of AA7075 aluminum alloy is evaluated through three different ageing heat treatments (T6, RRA and HTPP). In all ageing heat treatments, samples are taken into solid solution process at $485^{\circ} \mathrm{C}$ for $2 \mathrm{~h}$. After the quenching process, ageing processes were performed. The T6 ageing treatment is conducted at $120^{\circ} \mathrm{C}$ for $24 \mathrm{~h}$. Along the RRA ageing treatment, the samples taken to T6 operation retrogress at $120^{\circ} \mathrm{C}$ and are aged for $24 \mathrm{~h}$. In the HTPP ageing treatment, samples are pre-precipitated at $445^{\circ} \mathrm{C}$ for $30 \mathrm{~min}$ and taken into ageing process at $120^{\circ} \mathrm{C}$ for $24 \mathrm{~h}$ [11].

TABLE I

Chemical composition [wt\%] of the AA7075 alloy used in experimental studies.

\begin{tabular}{c|c|c|c|c|c|c|c|c}
\hline \hline $\mathrm{Al}$ & $\mathrm{Si}$ & $\mathrm{Fe}$ & $\mathrm{Mn}$ & $\mathrm{Cu}$ & $\mathrm{Mg}$ & $\mathrm{Zn}$ & $\mathrm{Cr}$ & $\mathrm{Zr}$ \\
\hline 89.6 & 0.403 & 0.549 & 0.014 & 1.568 & 2.596 & 5.480 & 0.0125 & 0.0305
\end{tabular}

The aged samples are subjected to standard metallographic processes for characterization studies and were etched with $2 \mathrm{ml} \mathrm{HF}, 90 \mathrm{ml}$ distilled water, $5 \mathrm{ml} \mathrm{HNO}_{3}$ and $3 \mathrm{ml} \mathrm{HCl}$ solution for $50-60 \mathrm{~s}$. Etched samples are 
examined through SEM+EDS, XRD, and hardness measurements. Hardness of alloy samples are determined by taking the mean value of five measurements taken from each samples by Shimadzu-made micro-hardness device (0.2 N load). Wear tests, based on the ASTM: G99-05 standards, are conducted by the standard pin-on disctype wear device. In these wear tests, $1 \mathrm{~m} \mathrm{~s}^{-1}$ sliding speed, $20 \mathrm{~N}$ load and four different sliding distance (300$1200 \mathrm{~m}$ ) are tested. Before these tests, abrasive disc and sample surfaces are cleaned with acetone. Worn samples is weighted by a precision scale so as to determine the relevant weight loss. AISI 4140 steel disk with 60-64 HRC hardness, $230 \mathrm{~mm}$ diameter and $20 \mathrm{~mm}$ thickness is used in the wear tests. After the wear tests, surfaces of samples are examined through the SEM.

\section{Results and discussion}

\subsection{Microstructural characterization and hardness}

The SEM images of AA7075 alloy samples applied different ageing heat treatments and samples not applied ageing process are given in Fig. 1. The images in Fig. 1 indicate no precipitation with non-aged samples of AA7075 alloy (Fig. 1a) and that there are second phase precipitation observed with samples applied T6, RRA and HTPP heat treatments. Measurements of precipitation size are indicated in Fig. 1b-d. While precipitations with the largest size are measured with the samples applied in HTPP heat treatment (Fig. 1b), the ones with smallest size were measured with the T6 process (Fig. 1c). The size of the precipitation obtained with the RRA ageing process (Fig. 1d) is in the range of the dimensions measured with the samples applied in the HTPP and T6 ageing processes. It is determined that hardness values measured are in conformity with the sizes of precipitations obtained during the second phase precipitations occurring as a result of different ageing processes. As for the hardness measurements, the hardness value of the non-aged AA7075 aluminum alloy samples is measured as $70 \mathrm{HV}$, and the hardness values of the samples applied HTPP, T6, and RRA heat treatments are determined as 146, 182, and $148 \mathrm{HV}$, respectively. It is concluded that different ageing processes applied on the AA7075 alloy demonstrate significant impact on hardness value of the alloy.

The XRD result of the samples applied T6 heat treatment is given in Fig. 2. According to the XRD result, $\mathrm{Mg}_{2} \mathrm{Si}$ precipitations are formed and can be observed in the structure. The second phase precipitations formed in the structure are the most significant factor developing resistance of the processed alloy. Previous studies reported that there were the second phases observed such as $\mathrm{Al}_{7} \mathrm{Cu}_{2} \mathrm{Fe}, \mathrm{Al}_{2} \mathrm{CuMg}$, and $\mathrm{Mg} 2 \mathrm{Si}[12,13]$.

\subsection{Wear test results}

Figure 3a exhibits weight losses and Fig. 3b friction coefficients measured with the AA7075 alloys applied different heat treatments under $1 \mathrm{~m} \mathrm{~s}^{-1}$ sliding speed, $20 \mathrm{~N}$ load and $1200 \mathrm{~m}$ sliding distance. Figure 3a shows the highest weight loss with the non-aged samples, and the
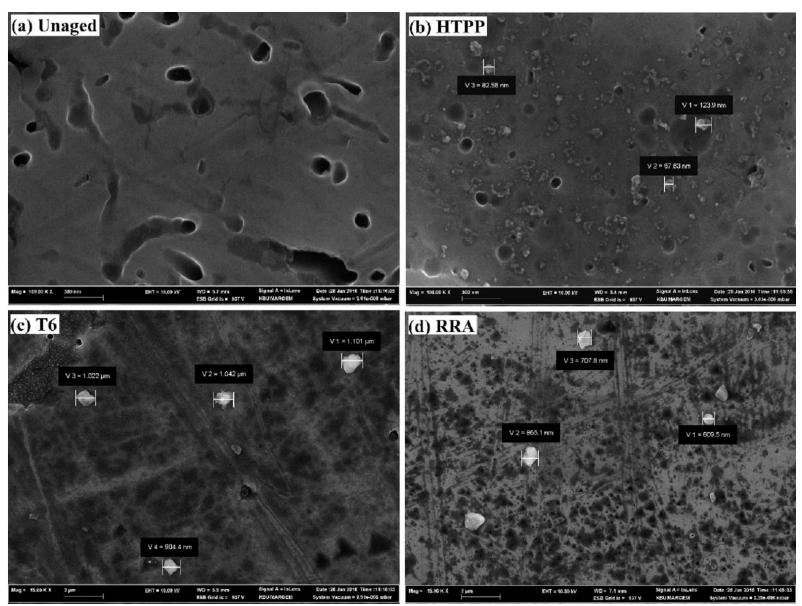

Fig. 1. Microstructure SEM images of the AA7075 alloys aged by different heat treatment processes: (a) nonaged, (b) T6, (c) RRA, (d) HTPP.

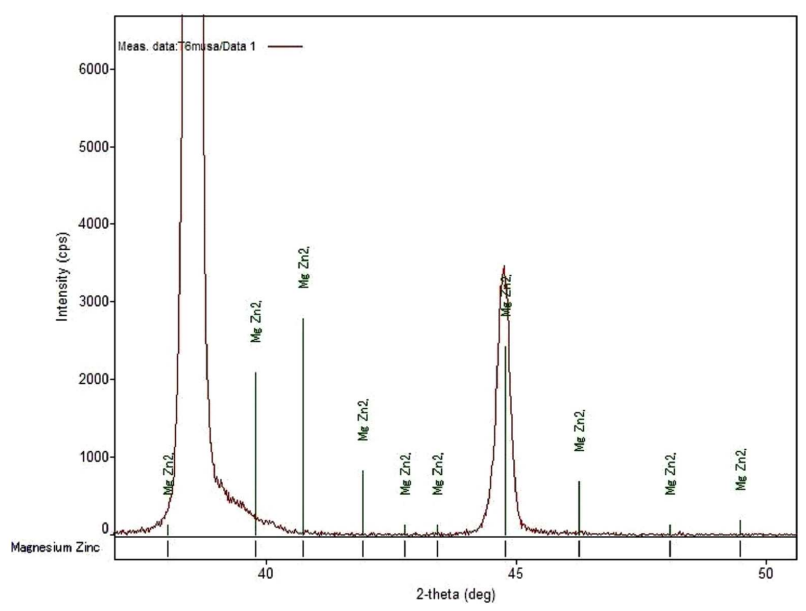

Fig. 2. XRD result of the AA7075 alloy aged by T6 process.

lowest weight loss with the one aged by T6 treatment. It was also observed that weight loss of AA7075 alloys incurred in the HPTT ageing treatment along $1200 \mathrm{~m}$ sliding distance is close to the weight loss of AA7075 alloys applied RRA ageing treatment. Comparison of measured weight loss hardness results indicates that they support each other. In Fig. 3b alloy hardness value is seen to be inversely proportional to the friction coefficient values. Moreover, as sliding distance increases, the relevant fiction coefficient values decrease.

Figure 4 shows SEM images of the worn surfaces of samples applied different ageing treatment processes under $20 \mathrm{~N}$ load and $1200 \mathrm{~m}$ sliding distance. According to the SEM images, direction of wear tracks could be observed clearly. Additionally, it could be observed from the SEM images that particles in various sizes were readhered onto the worn surface. According to the SEM images, non-aged samples have the highest weight loss 

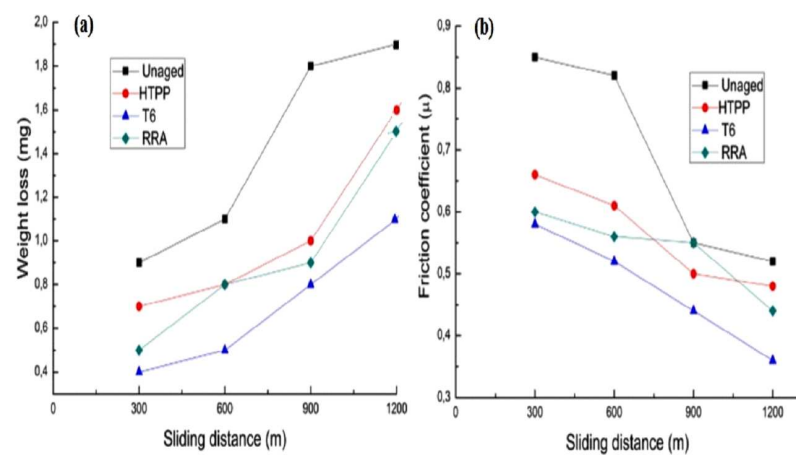

Fig. 3. Variation in (a) weight loss and (b) friction coefficient under $20 \mathrm{~N}$ load and $1200 \mathrm{~m}$ sliding distance.

(Fig. 4a) and there are particles adhered onto the sample surface. According to the SEM images of aged samples (T6, RRA and HTPP) (Fig. 4b-d) plastic deformation could also be seen on the samples and on the disc contact surface.
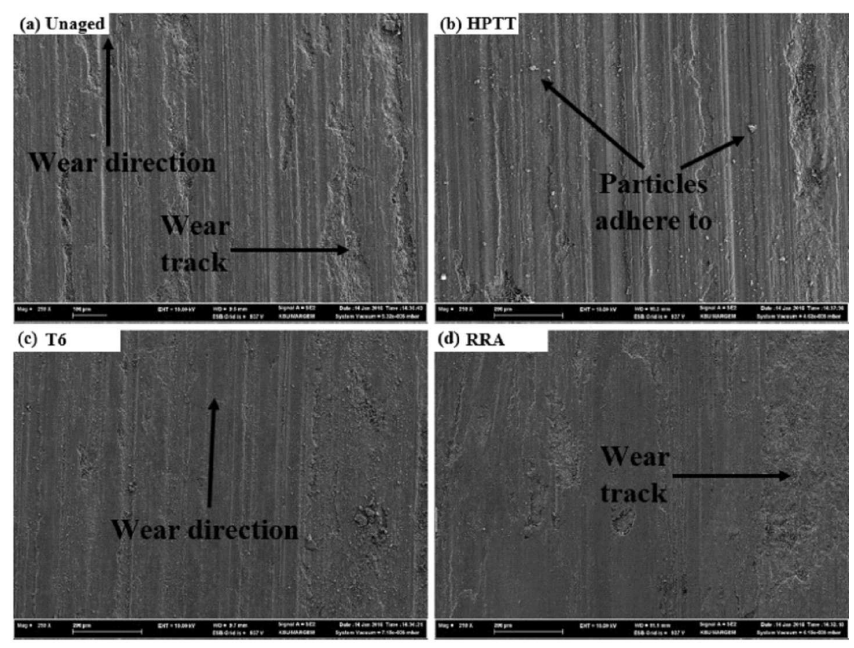

Fig. 4. SEM images of the worn surfaces of samples: (a) non-aged, (b) HTPP, (c) T6, (d) RRA.

\section{Conclusion}

In this study, different ageing treatments (T6, RRA, and HTPP) are applied to AA7075 alloy. Size of second phase precipitations shows difference according to the applied ageing process. While the smallest size precipitations are seen with the $\mathrm{T} 6$ ageing process, the coarse precipitations are obtained with the HTPP ageing process. Moreover, a relationship is determined between the size of second phase precipitation formed in the structure and measured hardness values. Whereas the highest weight loss was obtained with the non-aged samples during wear tests, the lowest weight loss was obtained with the samples aged by the T6 process.

\section{References}

[1] J.C. Williams, E.A. Starke, Acta Mater. 51, 5775 (2003).

[2] A. Heinz, A. Haszler, C. Keidel, S. Moldenhauer, R. Benedictus, W. Miller, Mater. Sci. Eng. A 280, $102(2000)$.

[3] W. Miller, L. Zhuang, J. Bottema, A. Wittebrood, P. De Smet, A. Haszler, A. Vieregge, $M a-$ ter. Sci. Eng. A 280, 37 (2000).

[4] T. Marlaud, A. Deschamps, F. Bley, W. Lefebvre, B. Baroux, Acta Mater. 58, 4814 (2010).

[5] C. Feng, Z. Liu, A. Ning, Y. Liu, S. Zeng, Trans. Nonferrous Met. Soc. China 16, 1163 (2006).

[6] G. Li, X. Zhang, P. Li, J. You, Trans. Nonferrous Met. Soc. China 20, 935 (2010).

[7] A. Fakioglu, D. Özyürek, R. Yllmaz, High Temp. Mater. Process. 32, 345 (2013).

[8] R. Yılmaz, D. Özyürek, E. Kibar, J. Fac. Eng. Archit. Gaz. 27, 429 (2012).

[9] H. Kaya, M. Uçar, A. Cengiz, D. Özyürek, A. Çalişkan, R.E. Ergül, Sci. Res. Essay 7, 2424 (2012).

[10] J.K. Parker, A.J. Ardell, Mater. Trans. A 15, 1531 (1984).

[11] A. Fakioglu, D. Özyürek, R. Yilmaz, High Temp. Mater. Process. 32, 345 (2012).

[12] N. Kamp, I. Sinclair, M.J. Starink, Metall. Mater. Trans. A 33, 1125 (2002).

[13] A. Abolhasani, A. Zarei-Hanzaki, H.R. Abedi, M.R. Rokni, Mater. Des. 34, 631 (2012). 